Edukids volume 17 (1) tahun 2020

EDUKIDS: Jurnal Pertumbuhan, Perkembangan, dan Pendidikan Anak Usia Dini

Jln. Dr. Setiabudhi No. 229 Kota Bandung 40154. e-mail: edukid@upi.edu website: http://ejournal.upi.edu/index.php/edukid

\title{
UPAYA AYAH DALAM MENERAPKAN PENDIDIKAN SEKS PADA ANAK USIA DINI
}

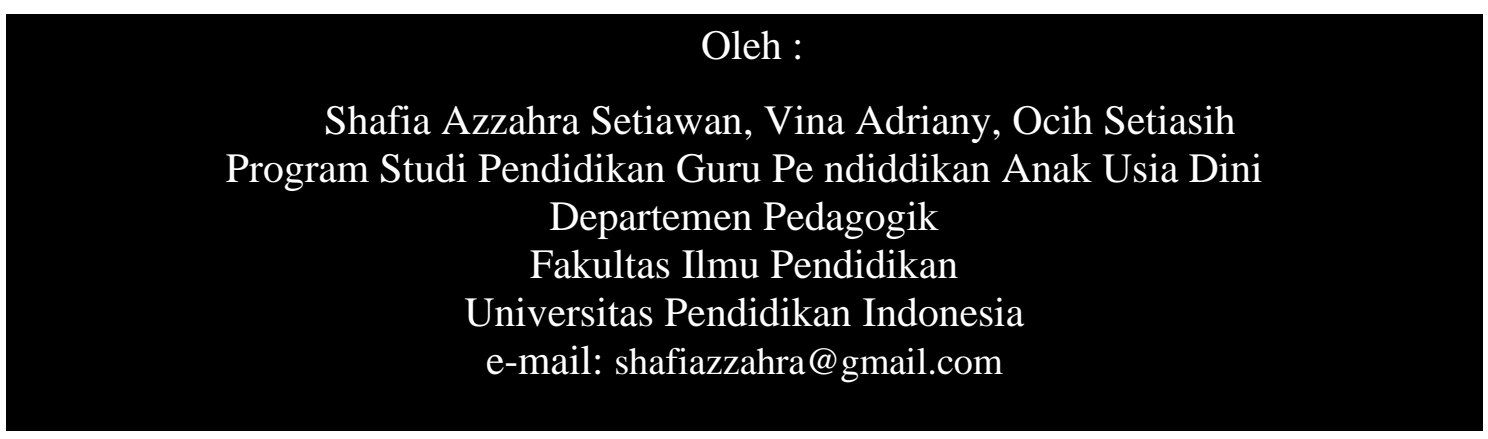

Abstrak: Penelitian ini bertujuan untuk mengetahui pandangan ayah mengenai pendidikan seks untuk anak, mengetahui peran ayah dalam menerapkan pendidikan seks kepada anak, dan untuk mengetahui hambatan apa saja yang dialami ayah saat memberikan pendidikan seks kepada anaknya. Penelitian dilakukan menggunakan pendekatan kualitatif dengan metode studi kasus, penelitian ini menggunakan teknik pengumpulan data yaitu wawancara dengan tiga orang responden. Adapun hasil temuan di lapangan sebagai berikut: persepsi responden mengenai pendidikan seks bahwa pendidikan seks untuk anak usia dini merupakan proses mengenalkan bagian tubuh yang boleh disentuh orang lain dan tidak boleh. Hambatan yang dialami ketiga responden dalam menerapkan pendidikan seks seperti merasa canggung saat membicarakan pendidikan seks kepada anaknya dan kekurangan informasi mengenai pendidikan seks sehingga kurang maksimal saat menerapkan kepada anaknya serta cara responden mengatasi hambatan tersebut dengan cara mencari informasi lebih mendalam mengenai pendidikan seks untuk anak dan melawan rasa canggung. Ayah yang berperan dalam pengasuhan dan pendidikan seks anak akan membuat anak merasa aman, nyaman, dan tidak kehilangan sosok ayah saat tumbuh dewasa. Dengan mengajarkan pendidikan seks pada anak, diharapkan dapat menghindarkan anak dari risiko negatif perilaku seksual maupun perilaku menyimpang.

Kata kunci : Peran Ayah, Pendidikan Seks, Anak Usia Dini 


\begin{abstract}
This research aims to determine fathers' perception on sex education for children, to know the role of the father in implementing sex education to children, and to find out what obstacles are experienced by fathers when they're teaching sex education to their children. The study was conducted using a qualitative approach with the case study method, this study uses data collection techniques, and interviewed three respondents. The findings in the field as follows: Respondents' perception toward sex education that is sex education for young children is a process of introducing the body part, and which part that may be touched with other people and should not be. The barriers experienced by the third respondent in applying sex education, he feels awkward when talking about sex education to their children, due to lack of information in sex education, so it is not maximum when he's teaching to their children and also how the respondents overcome these barriers by seeking more depth information in sex education for children and fight the awkwardness. Fathers who play a role in parenting and sex education will make children feel safe, comfortable, and have a figure of the father while they're growing up. By teaching sex education to children, it is expected to prevent children from the negative risk of sexual behavior and deviant behavior.
\end{abstract}

\title{
Keywords: Role of Fathers, Sex Education, Early Childhood
}

\section{PENDAHULUAN}

Anak usia dini memiliki hak yang sama dalam mendapatkan hak keamanan, kenyamanan, maupun kebahagiaan layaknya orang dewasa. Menurut Undang-Undang Republik Indonesia Nomor 23 tahun 2014 tentang Perlindungan Anak, pada Pasal 1 Ayat (2) disebutkan bahwa anak mendapatkan perlindungan yang mencakup segala kegiatan untuk menjamin dan melindungi anak dan hak- haknya agar dapat hidup, tumbuh, berkembang, dan berpartisipasi, secara optimal sesuai dengan harkat dan martabat kemanusiaan, serta mendapat perlindungan dari kekerasan dan diskriminasi. Dengan demikian, anak usia dini mempunyai hak untuk dilindungi oleh negara dari kekerasan secara jasmani maupun rohani.

Ironisnya, akhir-akhir ini semakin banyak kasus kekerasan pada anak usia dini, salah satunya adalah kekerasan seksual pada anak. Bahkan, catatan Komisi Perlindungan Anak Indonesia (KPAI) menyebutkan angka korban pelecehan seksual terhadap anak semakin tinggi setiap tahun. Pada tahun 2018 setidaknya terdapat 233 kasus kekerasan seksual pada dua bulan terakhir yakni bulan Februari dan Maret tahun 2018.

Meskipun demikian, sebenarnya pemerintah Indonesia telah berupaya dalam mencegah, memberantas, dan menghukum pelaku tindak pidana penjualan anak, prostitusi online, dan ponografi anak. Dalam UndangUndang Nomor 10 tahun 2012 tentang Pengesahan Protokol Konvensi yaitu pemerintah Republik Indonesia telah menandatangani Optional Protocol to the Convention on the Rights of the Child on the Sale of Children, Child Prostitution and Child Pornography pada tanggal 24 September 2001. Penandatanganan ini menjadi salah satu 
komitmen pemerintah terhadap masyarakat dalam implementasi Konvensi Hak-hak Anak merupakan hasil sidang Majelis Umum pada 20 November 1989, karena itu meningkatnya kasus kekerasan seksual pada anak merupakan bukti nyata bahwa hak anak untuk dilindungi dari segi kekerasan masih kurang bahkan pengetahuan anak mengenai pendidikan seks pun masih sangat kurang. Menurut Roqib (2008) pendidikan seks diberikan lebih awal disebabkan karakter dasar manusia itu dibentuk pada masa kanak-kanak, sedangkan menurut Nugraha (2010) pendidikan seks anak-anak perlu diberikan sedini mungkin dengan materi dan cara penyampaian pendidikan seks yang berbeda dengan orang dewasa, sehingga pendidikan seks yang paling baik untuk anak dilakukan oleh orang tua anak sendiri. Berdasarkan pernyataan di atas dapat disimpulkan bahwa selain anak harus dilindungi dari kekerasan, anak juga memiliki hak untuk mendapatkan informasi yang berhubungan dengan dirinya.

Ada banyak alasan mendasar mengapa pendidikan seks secara dini perlu dan penting bagi anak usia dini sesuai yang dikemukakan Tretsakis (1993) bahwa pendidikan seks secara dini akan memudahkan anak menerima keberadaan tubuhnya secara menyeluruh dan menerima fase-fase perkembangannya secara wajar. Pendidikan ini akan membantu anakanak untuk mampu membicarakan tentang seks dengan perasaan yang wajar. Pendidikan seks yang sehat cukup efektif untuk menghilangkan rasa ingin tahu yang tidak sehat dalam benak anak-anak.
Menurut Kriswanto (2006) seksualitas dapat diajarkan sedini mungkin yaitu sejak anak dilahirkan seperti saat orangtua memberikan rasa nyaman di tubuh anak dengan cara memberi sentuhan-sentuhan yang dilandasi kasih sayang misalnya saat memandikan dan menjaga kebersihan bayi. Hal itu akan berdampak pada penerimaan dirinya, anak merasa bahwa dirinya berharga, dicintai, disayangi, diperhatikan dan dirawat dengan baik. Dari fenomena yang ada, anak mempunyai rasa ingin tahu yang besar sehingga anak juga banyak yang menanyakan seputar seksualitas ditunjang dengan gencarnya pengaruh media massa. Di sisi lain ada orang tua yang merasa tabu untuk membicarakan seksualitas kepada anak maka diperlukan sikap yang positif dari orang tua baik dari ibu maupun ayah tentang pentingnya pendidikan seksual untuk anak.

Terdapat penelitian mengenai pendidikan seks untuk anak yang telah dilakukan oleh Sugiasih (2011) yang menjelaskan tentang peranan orang tua terutama ibu dalam memberikan informasi seksualitas kepada anak sangat besar. Dalam penelitian ini dapat disimpulkan bahwa ibu lebih banyak berperan dalam memberikan pendidikan seks padahal ayah juga memiliki peran dalam memberikan pendidikan seks untuk anak karena yang bertanggungjawab dalam memberikan pendidikan seks untuk anak adalah kedua orangtua nya bukan hanya ibu.

Ternyata masih banyak orang tua yang acuh tak acuh dan masih menganggap tabu dalam memberikan pendidikan seks untuk anak-anaknya. Maka dari itu, orang tua menyerahkan 
pendidikan seks kepada pihak sekolah, seperti pendapat dari Yafie (2017) yang bertanggung jawab untuk mengajar pendidikan seks pada anak usia dini adalah orang tua, sedangkan sekolah hanya sebagai pelengkap dalam memberikan informasi kepada anak. Hal ini menunjukkan bahwa peran orang tua, terutama ibu sangat strategis dalam memperkenalkan pendidikan seks dini untuk anak-anak mereka.

Selain peranan seorang ibu, ayah juga memiliki peranan penting dalam memberikan pendidikan seks untuk anak. Ayah yang terlibat dalam pengasuhan anak akan memiliki kemampuan sosial dan kognitif yang baik serta kepercayaan diri yang tinggi pada anak. Peran ayah dalam pengasuhan yang dilakukan secara optimal berpengaruh besar terhadap perkembangan anak. Hasil riset membuktikan bahwa ayah yang hangat membuat anak mudah menyesuaikan diri, lebih sehat secara seksual, dan intelektualnya berkembang lebih baik. Selain itu, anak lebih memiliki rasa humor, lebih percaya diri dan mempunyai motivasi belajar yang lebih baik (Vita, 2007, hlm. 11). Akan tetapi sangat disayangkan penelitian yang mengkaji tentang peran ayah dalam memberikan pendidikan seksual masih sedikit bahkan jarang ditemukan.

Ketika seorang ayah yang kurang berperan dalam menjalankan fungsi keayahannya akan membawa dampak yang buruk bagi anak. Terutama bagi perkembangan seksual maupun identitas seksual anak. Secara keseluruhan kehangatan yang ditunjukkan oleh ayah akan berpengaruh besar bagi kesehatan dan kesejahteraan psikologis anak, dan meminimalkan masalah perilaku yang terjadi pada anak (Rohner \& Veneziano, 2001).

Berdasarkan uraian masalah di atas, peneliti ingin melihat bagaimana seorang ayah menerapkan pendidikan seks untuk anaknya, atas dasar itu diperlukan analisis peran ayah dalam memberikan pendidikan seks untuk mencegah agar anak tidak mengalami pelecehan maupun kekerasan seksual.

\section{METODE PENELITIAN}

Berdasarkan judul yang diambil, desain yang digunakan dalam penelitian ini adalah desain penelitian deskriptif kualitatif. Menurut Sanjaya (2013) penelitian deskriptif kualitatif adalah metode penelitian yang menggambarkan secara utuh dan mendalam tentang realitas sosial dan berbagai fenomena yang terjadi di masyaraka yang menjadi subjek penelitian sehingga tergambarkan ciri, karakter, sifat, dan model dari fenomena tersebut. Penelitian berfokus pada upaya ayah dalam menerapkan pendidikan seks pada anak usia dini, sehingga peneliti memilih desain penelitian studi kasus. Penelitian kualitatif ini berfokus pada jenis data aktual dan prosedur pengumpulannya.

Data dari penelitian ini disajikan dalam bentuk deskriptif bersumber dari data yang telah dikumpulkan dari hasil wawancara. Berdasarkan hal tersebut pendekatan kualitatif dengan desain penelitian studi kasus dipilih karena peneliti bermaksud untuk melihat upaya ayah dalam menerapkan pendidikan seks pada anak usia dini. 


\section{HASIL PENELITIAN}

Pada pembahasan ini akan diuraikan tentang analisis temuan penelitian. Analisis dilakukan dengan mengacu pada berbagai teori yang mendukung temuan-temuan tersebut. Uraian ini sekaligus berfungsi sebagai jawaban atas pertanyaan penelitian yang telah ditetapkan sebelumnya sebagai berikut:

1. Bagaimana pandangan ayah terhadap pendidikan seks untuk anak usia dini?

2. Bagaimana peran ayah dalam penerapan pendidikan seks kepada anaknya?

3. Apa saja hambatan ayah dalam memberikan pendidikan seks untuk anak usia dini?

Uraian berikut akan menjelaskan tentang ketiga pertanyaan penelitian, terdapat delapan sub-tema, yaitu: 1) Pemahaman Ayah mengenai Pendidikan Seks untuk anak, 2) Pemahaman Ayah terhadap Pentingnya Pendidikan Seks untuk Anak, 3) Halhal yang Dilakukan Ayah dalam Memberikan Pendidikan Seks Kepada Anak, 4) Waktu yang Diluangkan Ayah dalam Memberikan Pendidikan Seks untuk Anak, 5) Cara Mengalihkan Perhatian Anak dari Hal-hal yang Tidak Boleh Dilihat, 6) Mengajarkan Anak untuk Permisi Terlebih Dahulu Sebelum Masuk ke Kamar Orangtua, 7) Mengetahui Tingkat Pemahaman Anak Mengenai Pendidikan Seks , 8) Hambatan Menerapkan Pendidikan Seks kepada Anak dan Cara Menangani Hambatan.

\section{Pemahaman Ayah mengenai Pendidikan Seks untuk Anak}

Berbicara tentang pendidikan seks tentu akan berkaitan dengan pengertian pendidikan secara umum. Pendidikan seks yang diajarkan kepada anak sering difokuskan pada pengenalan identitas anak sebagai makhluk biologis yang memiliki jenis kelamin. Banyak yang salah paham jika pendidikan seks hanya mengajarkan cara untuk melakukan hubungan seks saja. Padahal, pendidikan seks memberikan pemahaman yang lebih luas dan disesuaikan dengan tingkat usia anak. Tidak hanya itu, anak juga jadi memahami mengenai fungsi-fungsi alat seksual hingga naluri yang bisa timbul kapan saja.

Pendidikan seks merupakan upaya transfer pengetahuan dan nilai (knowledge and values) tentang fisikgenetik dan fungsinya khususnya yang terkait dengan jenis kelamin (sex) lakilaki dan perempuan sebagai kelanjutan dari kecenderungan primitif makhluk hewan dan manusia yang tertarik dan mencintai lain jenisnya (Roqib, 2008). Selain upaya dalam transfer pengetahuan dan nilai seperti apa yang dikatakan peneliti di atas, pendidikan seks diajarkan supaya anak mengetahui rasa malu pada dirinya, mengajarkan tidur terpisah dengan kakak/adik nya yang berbeda jenis kelamin, dan mengalihkan perhatian anak dari halhal yang seharusnya dilihat anak pada usia tersebut.

Pemahaman lain dikemukakan oleh bapak Kevin bahwa pendidikan seks diterapkan untuk mengenalkan kepada anak bagian tubuh dan bagian tubuh mana saja yang tidak boleh disentuh orang lain. Pendidikan seks adalah proses pendewasaan anakdalam 
mengetahui jati dirinya sebagai lakilaki atau perempuan menurut bapak Putra Seperti yang dikemukakan Ratnasari \& Alias (2016) bahwa pendidikan seks merupakan pengajaran, penyadaran, dan pemberian informasi tentang masalah seksual. Bagaimana fungsi kelamin sebagai alat reproduksi.

\section{Pemahaman Ayah terhadap Pentingnya Pendidikan Seks untuk Anak}

Pada bagian sebelumnya, peneliti memaparkan pandangan ayah mengenai pendidikan seks untuk anak yaitu upaya memberikan pengetahuan mengenai tubuh anak, fungsi, cara merawat, mengenal jati dirinya sebagai laki-laki atau perempuan, dan mengajarkan bagian-bagian tubuh mana saja yang tidak boleh dipegang oleh orang lain. Dengan demikian dapat ditarik kesimpulan bahwa pendidikan seks penting diajarkan kepada anak. Seperti yang dikemukakan oleh bapak Putra dalam wawancara yang mengungkapkan bahwa pendidikan seks sangat penting diajarkan kepada anak karena bila anak tidak mengenal jati dirinya sebagai laki-laki atau perempuan nanti akan kebingungan mengenai identitas dirinya dan akan condong ke arah yang berlawanan, hal serupa juga dikemukakan oleh bapak Adam bahwa pendidikan seks penting diterapkan kepada anak karena anak mengenal fitrahnya dan lebih menjaga kesehatan. Bapak Kevin juga berpendapat pendidikan seks penting diterapkan kepada anak karena banyaknya kejadian-kejadian yang membahayakan anak jika anak tidak dibekali ilmu pendidikan seks terlebih dahulu.
Dari pernyataan di atas dapat disimpulkan bahwa alasan penting dari memberikan pendidikan seks untuk anak termasuk anak usia dini salah satunya adalah untuk menghindari pelecehan seksual atau kekerasan seksual kepada anak dengan cara mengajarkan anak tentang pendidikan seks. Pernyataan di atas diperkuat dengan teori dari Finkelhor (2009 hlm. 179) mengatakan bahwa tujuan utama upaya pencegahan pelecehan seks terhadap anak pada bidang pendidikan (pemberian pendidikan seks) adalah untuk membantu anak dapat terampil mengidentifikasi situasi-situasi berbahaya dan mencegah terjadinya pelecehan seks, serta mengajarkan pada anak bentuk-bentuk sentuhan yang tidak baik, bagaimana cara menolak atau mengakhiri interaksi dengan pelaku atau orang yang mencurigakan, serta bagaimana cara meminta pertolongan. Penulis berpendapat bahwa pandangan beberapa ayah yang diwawancara terhadap pendidikan seks untuk anak usia dini masih berupa pengenalan anggota tubuh dan perbedaan jenis kelamin, namun peneliti menemukan ada hal lain yang juga harus dijelaskan ayah kepada anak seperti dalam Camelia (2017) adalah bagaimana proses melahirkan pada manusia atau lebih tepatnya adalah proses pembuahan agar anak juga mengerti fungsi organ tubuhnya secara konstekstual dan dengan menegaskan proses pembuahan dan melahirkan hanya dibolehkan untuk orang dewasa yang organ tubuhnya sudah matang. 


\section{Hal-hal yang Dilakukan Ayah dalam Memberikan Pendidikan Seks Kepada Anak}

Berdasarkan hasil wawancara peneliti dengan tiga orang responden, peneliti menemukan hal apa saja yang dilakukan ayah dalam memberikan pendidikan seks kepada anaknya seperti membudayakan malu, mengajarkan bagian tubuh yang tidak boleh disentuh oleh orang lain, dan memberitahu apa yang boleh dan tidak boleh dilihat anak diusianya. Hal serupa juga dikemukakan oleh bapak Putra bahwa selain mengajarkan rasa malu kepada anak, anak juga diajarkan perbedaan dari cara berpakaian dan menjelaskan perbedaan laki-laki dan perempuan dari video agar menarik perhatian anak. Dari pernyataan bapak Putra dapat disimpulkan bahwa selain dengan membudayakan malu anak juga diajarkan perbedaan pakaian laki-laki dan perempuan untuk memperjelas identitas diri anak. Hal lain yang diajarkan adalah dengan memberitahu kepada anak bagian tubuh mana saja yang tidak boleh disentuh/pegang oleh orang lain.

Dari pernyataan ketiga responden di atas dapat dilihat bahwa ada caracara untuk mengajarkan anak mengenai pendidikan seksual. Namun selain dengan cara yang dipaparkan responden, peneliti menemukan cara lain yaitu dengan memberikan pendidikan seks pada anak ketika mandi, hal ini sejalan dengan teori yang dikemukakan oleh Bichler dan Snowman yang mengungkapkan bahwa anak prasekolah adalah mereka yang berusia 3-6 tahun dan senang mengeksplorasi anggota tubuh mereka dengan dan atau tanpa orang tua. Sehingga ketika orang tua memberikan materi pendidikan seks saat sedang mandi anak bisa lebih menyerap apa yang diajarkan karena melihat langsung anggota tubuh yang dikenalkan. Seperti yang telah peneliti paparkan menurut Ilmawati (dalam Listiyana, 2012) pokok-pokok pendidikan seks yang bersifat praktis, yang perlu diterapkan dan diajarkan kepada anak adalah sebagai berikut :

1) Menanamkan rasa malu pada anak. Rasa malu harus ditanamkan kepada anak sejak dini. Jangan biasakan anak-anak, walau masih kecil, bertelanjang di depan orang lain; misalnya ketika keluar kamar mandi, berganti pakaian, dan sebagainya. Membiasakan anak sejak kecil untuk selalu menutup bagian sensitif.

2) Menanamkan jiwa maskulinitas pada anak lakilaki dan jiwa feminitas pada anak perempuan. Secara fisik maupun psikis, laki-laki dan perempuan mempunyai perbedaan mendasar. Adanya perbedaan ini bukan untuk saling merendahkan, namun semata-mata karena fungsi yang berbeda yang kelak akan diperankan anak.

\section{Waktu yang Diluangkan Ayah dalam Memberikan Pendidikan Seks untuk Anak}

Berdasarkan hasil wawancara ditemukan bahwa ketiga partisipan memiliki waktu-waktu yang diluangkan untuk memberikan pendidikan seks kepada anaknya. Dapat ditemukan bahwa waktu yang diluangkan ayah untuk memberikan 
Pendidikan seks kepada anaknya pada saat pulang dari kantor, saat anak selesai mandi, atau saat anak sedang menonton film kartun. Seperti yang dikemukakan oleh bapak Putra dan bapak Kevin saat wawancara namun bapak Kevin memiliki waktu yang tidak tentu dalam memberikan pendidikan seks kepada anaknya.

Berdasarkan jawaban di atas dapat disimpulkan bahwa setiap ayah memiliki waktu yang berbeda saat memberikan pendidikan seks kepada anaknya seperti saat libur kantor, saat anak hendak mandi karena anak akan melihat langsung bagian-bagian tubuhnya, atau pada saat mendampingi anaknya menonton. Seperti yang diungkapkan oleh Safita (2013) saat memandikan si kecil, Anda bisa memberitahu berbagai organ tubuh anak, seperti rambut, kepala, tangan, kaki, perut, dan jangan lupa penis dan vagina atau vulva. Lalu terangkan perbedaan alat kelamin dari lawan jenisnya, misalnya jika si kecil memiliki adik yang berlawanan jenis.

\section{Cara Mengalihkan Perhatian Anak dari Hal-hal yang Tidak Boleh Dilihat}

Dalam bagian ini peneliti menemukan cara untuk mengalihkan perhatian anak dari hal yang tidak boleh dilihat atau tidak boleh dilakukan pada anak dari responden dalam wawancara.

Mengalihkan perhatian anak dari hal yang tidak boleh dilihat bisa dengan cara mengajak anak bermain dan menonton tv. Namun selain dengan cara yang dipaparkan responden, peneliti menemukan cara lain untuk mengalihkan perhatian anak dengan cara bercerita sekaligus memberikan penjelasan mengenai perbedaan antara anak laki-laki dan anak perempuan dan dari hal-hal yang tidak boleh dilihat serta alasannya. Terkadang orangtua juga dapat memanfaatkan momen untuk mengajarkan kepada anak akan perbedaan. Misalnya orangtua dapat mengatakan "iya, anak laki-laki dan perempuan memiliki tubuh yang berbeda, tetapi setiap orang adalah spesial. Anak perempuan akan tumbuh menjadi wanita dewasa dan anak lakilaki akan tumbuh menjadi pria dewasa."

\section{Mengajarkan Anak untuk Permisi Terlebih Dahulu Sebelum Masuk ke Kamar Orangtua}

Hal menarik yang peneliti dapatkan saat wawancara dengan salah satu responden adalah cara seorang ayah mengajarkan kepada anak untuk selalu memberi salam dahulu sebelum masuk ke kamar orangtuanya karena hal semacam ini masih dianggap kurang penting bagi sebagian kalangan orangtua.

Dari pernyataan bapak Adam dalam wawancara dapat disimpulkan bahwa anak harus permisi terlebih dahulu sebelum memasuki kamar orangtuanya karena orangtua memiliki waktu intim. Hal tersebut diperkuat dengan teori dari Nawangsari (2015) bahwa anjuran isti'dzân (meminta ijin) dilakukan dalam bentuk permintaan ijin bagi anak-anak yang belum baligh dalam bentuk pemberian toleransi untuk memasuki kamar kedua orang tuanya kecuali pada tiga waktu yaitu sebelum shalat subuh, pada saat tengah hari, dan setelah isya. Hal ini dimaksudkan agar anak mengetahui hukumhukum yang berkaitan dengan 
aurat, hubungan seksual dan keadaan orang lain.

\section{Mengetahui Tingkat Pemahaman Anak Mengenai Pendidikan Seks}

Pada bagian-bagian sebelumnya peneliti sudah memaparkan bagaimana seorang ayah memberikan pendidikan seks kepada anaknya, di bagian ini peneliti akan memaparkan tingkat pemahaman anak mengenai pendidikan seks yang sudah diberikan oleh ayah atau orangtuanya. Tidak semua anak akan langsung paham mengenai apa yang sudah diajarkan oleh orangtuanya maka dari itu saat memberikan pendidikan kepada harus sabar, terkadang anak pun lupa dengan apa yang sudah diajarkan dan harus selalu diingatkan kembali seperti yang dikemukakan oleh bapak Adam dalam wawancara, hal serupa juga dikemukakan oleh bapak Kevin karena anaknya sudah paham dengan apa yang diajarkan ayahnya dengan menunjukkan perbedaan anak laki-laki dan anak perempuan serta sudah bisa menunjukkan anggota tubuh yang harus tertutup.

Dalam wawancara tersebut disertai data yang diperoleh anak umur 5 tahun yaitu anak bapak Adam sudah paham bahwa malu jika membuka baju didepan orang lain dan anak bapak Kevin yang sudah berumur 5 tahun yang sudah bisa menyebutkan anggota tubuh yang harus ditutup. Hal ini diperkuat dengan teori yang dikemukakan oleh Freud (Andika, 2010:45) bahwa tahapan dalam perkembangan psikoseksual yang dilalui anak terbagi menjadi empat fase. salah satu fasenya yaitu ketika memasuki umur empat tahun, anak sudah mulai menyadari perbedaan antara dirinya dengan temanya yang berbeda jenis kelamin. Fase ini disebut masa Phallusbahwa. Jadi dari teori di atas dapat disimpulkan bahwa anak yang sudah berumur empat tahun sudah mengenali jenis kelaminnya sendiri.

\section{Hambatan Menerapkan \\ Pendidikan Seks kepada Anak dan Cara Menangani Hambatan}

Berdasarkan hasil wawancara peneliti dengan tiga responden, peneliti menemukan berbagai hambatan yang dialami ayah dalam menerapkan pendidikan seks untuk anak-anaknya, ayah pun memiliki hambatan seperti canggung karena pendidikan seks merupakan hal yang masih dianggap hal yang sensitif untuk dibicarakan kepada anak ataupun ayah merasa kurang informasi mengenai pendidikan seks kepada anak-anaknya. Selain rasa canggung dan kurangnya informasi mengenai pendidikan seks yang dialami bapak Putra hal lain seperti anak yang mudah lupa dialami oleh bapak Adam seperti yang dikemukakan. Seperti halnya bapak Putra yang memiliki hambatan dalam pengetahuan mengenai pendidikan seks bapak Kevin juga memiliki hambatan yang sama yaitu pengetahuan tentang pendidikan seks untuk anak masih kurang dari diri bapak Kevin sendiri seperti yang diungkapkan dalam wawancara.

Dari pernyataan-pernyataan responden di atas dapat diambil kesimpulan bahwa kurangnya pemahaman pendidikan seks untuk anak bisa menjadi hambatan dalam menerapkan pendidikan seks kepada anak secara langsung. Hal ini diperkuat 
dengan teori bahwa Kurangnya pemahaman orang tua tentang pengetahuan seks menjadi salah satu kendala komunikasi orang tua dengan anak.

Cara masing-masing responden menangani hambatan yang dialami dalam menerapkan pendidikan seks kepada anak-anaknya. Seperti bapak Putra yang menangani hambatan dengan cara dipaksakan kecanggungannya dan mencari informasi-informasi terkait seperti yang diungkapkan pada wawancara, hal serupa juga dikemukakan oleh bapak Kevin yang mencari tahu bagaimana dan berdiskusi dengan orang yang sudah berpengalaman mengenai hal itu. Berdasarkan hasil wawancara di atas dapat disimpulkan bahwa mencari tahu lebih lanjut di internet ataupun dengan berdiskusi dengan orang yang lebih berpengalaman dapat meminimalisir hambatan yang terjadi dalam mengajarkan pendidikan seks. Seperti yang diungkapkan Nurul (2012) yaitu pentingnya informasi tentang seks untuk mengatasi informasi yang negatif di luar lingkup keluarga.

\section{KESIMPULAN}

Ayah memiliki pandangan bahwa pendidikan seks untuk anak usia dini merupakan proses mengenalkan bagian tubuh yang boleh disentuh orang lain dan tidak boleh, Selain itu pendidikan seks juga bertujuan untuk mengajarkan anak tentang rasa malu dan agar mengetahui jati dirinya. Ayah memiliki peranan penting dalam pendidikan seks agar anak dapat menumbuhkan sikap tegas dan disiplin mengenai gendernya sendiri, selain itu anak perempuan yang memiliki kedekatan dengan ayahnya sejak di usia dini akan merasa aman dan nyaman sehingga tidak mudah akan mudah terkena rayuan laki-laki yang tidak bertanggungjawab di saat anak beranjak dewasa. Cara yang ayah lakukan dalam menerapkan pendidikan seks kepada anaknya dengan cara menerapkan rasa malu, membedakan pakaian untuk perempuan dan laki-laki, dan mengajarkan bagian tubuh mana saja yang tidak boleh disentuh oleh orang lain.

\section{DAFTAR PUSTAKA}

Andika, Alya. 2010. Bicara Seks Bersama Anak. Yogyakarta: Pustaka Anggrek

Camelia, L dan Nirmala, I. (2017). Penerapan Pendidikan Seks Anak Usia Dini Menurut Perspektif Islam. Yaa Bunayya: Jurnal Pendidikan Anak Usia Dini. 1(1). 27-32

Finkelhor, D. (2009). Children's exposure to violence: A comprehensive national survey. DIANE Publishing. Hal. 179

Kriswanto, C. (2006). Seks, Es Krim dan Kopi Susu. Jakarta : Jagadnita.

Listiyana, A. (2012). Peranan ibu dalam mengenalkan pendidikan seks pada anak usia dini. EGALITA.

Nawangsari, D. (2015). Urgensi pendidikan seks dalam islam. TADRIS: Jurnal Pendidikan Islam, 10(1), 74-89.

Nugraha, B.D. (2010). Jurnal pendidikan, perlunya pendidikan seks pada anak sejak usia Dini. Jakarta:

Gramedia 
Nurul, C. (2012), Pendidikan Seks untuk anak.Solo: Aqwam Solo

Ratnasari, R. F., \& Alias, M. (2016). Pentingnya pendidikan seks untuk anak usia dini. Tarbawi Khatulistiwa, 2(2), 55-59.

Rohner, R. P., \& Veneziano, R. A. (2001). The importance of father love: History and contemporary evidence. Review of General Psychology, 5(4), 382-405. doi: 10.1037/10892680.5.4.382

Roqib, M. (2008). Jurnal alternatif pendidikan, pendidikan seks untuk anak usia dini. Purwokerto: P3M STAIN.

Safita, R. (2013). Peranan orang tua dalam memberikan pendidikan seksual pada anak. Jurnal EduBio, 4, 32-40.

Sanjaya, Wina. 2013. Penelitian Pendidikan, Jenis, Metode dan Prosedur. Jakarta: Kencana Prenada Media Group.

Sugiasih, I. 2011. Need assessment mengenai pemberian pendidikan seksual yang dilakukan ibu untuk anak usia 3-5 tahun. Jurnal Psikologi Proyeksi, 6(1).

Tretsakis, M. (2003). Seks \& Anakanak.Bandung: CV. Pionir Jaya.
Undang-Undang Republik Indonesia Nomor 10 Tahun 2012 tentang Pengesahan Optional Protocol To The Convention On TheRights Of The Child On The Sale Of Children, Child Prostitution And Child Pornography (Protokol Opsional Konvensi Hak-Hak Anak Mengenai Penjualan Anak, Prostitusi Anak, Dan Pornografi Anak).

Undang-Undang Republik Indonesia Nomor 23 Tahun 2002 tentang Perlindungan Anak.

Vita. 2007. Peran Ayah dalam Pengasuhan Anak. (http:// www.bkkbn.go.idIgemapria/ article-detail.php?artid $=\quad 82$. diakses tanggal 28 februari 2019)

Yafie, E. (2017). Peran Orang Tua Dalam Memberikan Pendidikan Seksual Anak Usia Dini. Jurnal CARE (Children Advisory Research and Education), 4(2). 